\section{Orchards During War: Braceros in the Northwest}

John Fabian

Junior, History

The bracero workers of the

American Northwest staged labor stoppages

between 1942 and 1947 due to neglect from the American and Mexican governments. With the outbreak of World War II, a huge demand for labor had risen in the United States, especially in the states of Idaho, Washington and Oregon. The United States government introduced an agreement with the Mexican government to allow Mexican laborers to work in the United States on a temporary basis. These workers were dubbed "braceros", a Spanish term for manual laborers. Although American farms and railroads had a demand for Mexican labor, the treatment of these individuals varied. The Mexican government had oversight on the working conditions of these laborers, but the American Southwest gained more attention than the American

Northwest. As a result, the braceros of the Northwest often took measures into their own hands by staging work stoppages. Although some laborers received poor treatment, many braceros looked back upon their work experience in the 1940s as positive experience in their lives.

Mexican labor existed in the American Northwest before the onset of World War II, but not to a large extent. A majority of the crops grown in the American Northwest had a high perishability rate. As a result, when these crops were in season, a huge labor pool was needed in order to retrieve the harvest before the produce went bad. However, Mexican laborers historically were not used to gather these crops. It was much more likely for a Washington farmer to hire migrant American workers rather than Mexicans. The American Northwest simply did not have the Mexican presence that the American Southwest did, due to its distance from the Mexican border. Any presence of Mexican labor in the American Northwest pre-World War II was likely found in the railroad industry. In 1909, Mexicans made up 17.1 percent of the Northwestern railroad industry, and in 1929 this number went up to 59.5 percent. ${ }^{1}$ Before the bracero program, these Mexican laborers would sign contracts with their employers called "enganches." A major aspect of these contracts was to withhold 10 percent of these laborers' pay until their time of service had ended. The 10 percent was then sent to them once they returned to Mexico. The purpose of this hold back was to ensure that Mexican laborers would return to Mexico after their contracts had expired. ${ }^{2}$ The bracero program was later modeled after the enganches. The officials that crafted the bracero program were intent on ensuring that Mexican laborers would return to Mexico after their contracts expired. ${ }^{3}$

Most Americans were hesitant to allow Mexicans entry into the United States, as they preferred American jobs go to American citizens. But the entry of the United States into World War II absorbed a large amount of the labor force into either the armed services or industries related to 
defense. The demand for agricultural goods skyrocketed due to the destruction of agricultural production in Europe. Labor shortages for agriculture were critical in the Northwest. The Amalgamated Sugar Company in Oregon hired an outside firm to track down laborers and they only found five hundred men readily available. ${ }^{4}$ Some schools changed to a six days a week schedule in order to ensure that the summers would be longer for teenagers to work the fields. ${ }^{5}$ Congress also passed a law which limited the entrance of Asians into the country, lowering the labor pool even more. ${ }^{6}$ The solution the United States government crafted to solve this problem was to allow Mexicans to come work in the agriculture and railroad industries on a temporary basis.

On August $7^{\text {th }} 1942$, the State Department announced that they would allow Mexican workers to enter the United States to combat the labor shortage. In their announcement, the United States government promised these workers steady wage rates, adequate living conditions, and a paid return to Mexico at the end of their contracts. However, they emphasized that these workers were not to be used to replace American workers. ${ }^{7}$ The United States also included a provision that allowed for the Mexican government to monitor the working conditions of the braceros to ensure that they were not being abused. ${ }^{8}$ The program was officially known as the Mexican Farm Labor Program, and the Office of Labor which reported to the Department of Agriculture, monitored it. The nation was split into administrative districts under the program, with one of them being the Pacific Northwest Division consisting of Washington, Oregon, Idaho, Montana, Wyoming, and Utah. ${ }^{9}$

The Mexican government advertised the bracero program to rural communities through the means of newspaper, radio, and word of mouth. Since they specifically targeted rural areas, many of the braceros were uneducated. Workers often did not have proper clothing for colder climates like the Northwest because they were not told where they were going to work beforehand..$^{10}$ Bracero workers also rarely stayed in one place for a long time. Bracero worker Francisco Murillo Almaráz recounted how he worked in Arizona, California, Idaho, Montana and Washington throughout his career. ${ }^{11}$ Another requirement for bracero workers was that they had to be landless to be considered for acceptance. When applying for work, braceros had their hands checked to ensure that they had the rough and cracked hands of a farmer. ${ }^{12}$ Since most bracero workers were uneducated, most of them did not fully understand the contracts which were given to them. Many of these workers were very desperate for work as well. Workers such as Francisco Murillo Almaráz and Miguel Arroyo Castillo were concerned that they would be forced to fight in the armed services, but were willing to take the risk and enter the program because they needed the money. ${ }^{13}{ }^{14}$ One could argue that the bracero workers were particularly vulnerable to abuse because the average worker was uneducated and were sent to work for farmers in English 
speaking regions, with few or no Spanish translators available. ${ }^{15}$ Most of the workers came from impoverished regions and had a demand for employment, no matter how grueling the work was.

The main line of defense for the braceros was supposed to be the Mexican consulate and their inspectors. In reality, the effectiveness of the Mexican government at protecting the braceros was mixed, and sometimes counterproductive. One major issue for bracero workers in the Northwest was that the Mexican government originally only provided two labor inspectors for the entire region. ${ }^{16}$ Also, the only Mexican consulate in the Northwest was located in Salt Lake City, Utah. ${ }^{17}$ Considering that most bracero workers were poor, it would have been extremely difficult and unrealistic for the average worker to gain the means of transportation to travel to Salt Lake City just to report a labor issue. Mexican inspectors were also rarely chosen on their ability to monitor labor abuses, and instead were generally given their position because they had connections with the Mexican Minister of Labor. Inspectors in the Southwest also seemed to take a larger administrative effort to stop labor abuse then their counterparts the Northwest. In Texas, Consul General Miguel Calderon actively fought for the Texas' Good Neighbor Commission to be created so that workers could be better taken care of. ${ }^{18}$ No such effort was made in the Pacific Northwest to protect the workers in the way that had been done in the Southwest.
The War Food Administration (WFA) of the United States also played an active role in trying to limit the effectiveness of these labor inspectors. Since the war required a substantial amount of food, the WFA was willing to protect farmers who provided subpar working conditions if it meant greater output. As a result, Mexican officials were closely monitored by the WFA in order to ensure that they did not bring agriculture production to a halt. ${ }^{19} \mathrm{In}$ some instances the Mexican government was willing to assist the United States in suppressing the bracero workers' complaints. In one instance, the Mexican government declared that the issues of strikes among the braceros was a political issue for the United States government to resolve, not Mexico's. Confusion also existed between the Mexican government and the United States, with the United States saying one thing and doing another. For example, the Department of Labor declared that braceros would be removed from Imperial Valley in California in order to appease local farmers. However, the United States ambassador to Mexico informed the Mexican government behind closed doors that the United States would in fact not remove the workers as they had announced and they remained in the Imperial Valley. ${ }^{20}$ The Mexican government did not have much to gain by actively fighting the United States, as long as braceros were sending money back home.

In fairness, some Mexican inspectors in the Northwest did make some attempts at improving the living standards for workers, 
at least when it came to issues of discrimination. In an account from bracero Juan Contreras, he mentions how he was once refused service at a local restaurant which also had a discriminatory sign in its window. He complained to the Mexican consul and shortly after the sign was removed. ${ }^{21}$ In another account, the Mexican secretary of foreign affairs Alfonso Guerra went on a trip to Boise, Idaho and noticed a restaurant had a sign that read "No Mexicans allowed." Guerra then threatened to have all braceros relocated from Idaho if the sign was not removed. ${ }^{22}$ Miguel Arroyo Castillo, who was a bracero in Idaho recounted that on many occasions government officials visited their camps to make sure they were being treated well. Although some inspectors may have actually tried to protect the braceros of the Northwest, it was clear that there simply were not enough inspectors to effectively monitor an area that vast, with that many workers. $^{23}$

One of the main hardships of bracero workers were the subpar housing conditions provided to them. The United States government guaranteed adequate housing conditions to bracero workers, but failed to ever specify exactly what "adequate" meant. As a result, housing conditions provided by farmers varied from good to horrendous all throughout the Pacific Northwest. Many farmers were unprepared for the influx of Mexican laborers, and camps had to be constructed for them en mass. Sometimes camps were built on land that recently had been cleared. Once the soil of this land dried, the constant foot and vehicle traffic caused there to be tremendous amounts of dust within these camps. There was once an instance in an Oregon camp where it was constructed so poorly that after a windstorm, twenty-one tents were lifted in the air and destroyed. The tents also provided almost no insulation in the winter, as the loose ends of the tents allowed heat to escape. Some camps did not even have enough kerosene or wood to keep the laborers warm in the winter months. Housing facilities were also unsafe. For example, in October of 1944 there was a camp in Marsing, Idaho that had an oil burning water heater explode which destroyed everything in its vicinity. ${ }^{24}$ The tight quarters and poor conditions also contributed to spreading many diseases, such as respiratory, and gastrointestinal illnesses. $^{25}$

Railroads in the Northwest arguably provided even worse housing conditions than the farmers did. In Crescent Lake, Oregon not enough bunkhouses were constructed to house all of the workers at once. As a result, half the workers would work a twelve hour shift while the other half got to sleep in the bunkhouses. When a workers shift was over they would just switch with another worker. The housing that the Northern Pacific Railway provided in Seattle was extremely unsanitary. There were no screens on the doors and garbage pooled up outside of housing facilities. The latrines became so unsanitary that workers decided to stop using them and found other places to defecate. Some braceros did not even have stationary living quarters. 
Depending on what line a bracero worked for on the Southern Pacific Railroad, they would be forced to sleep in boxcars. In one case, nine people lived in one car with only steel cots to sleep on. The car itself only had one stove which was used for cooking and heating. At a number of housing facilities the only source of water consisted of overhead tanks that could only be filled by train cars coming by. If no trains were scheduled to pass, the tanks would not be filled. The absence of hygiene in these facilities also led to bedbugs. ${ }^{26}$

Some braceros got lucky and were provided suitable housing conditions. For example, the Pacific Fruit Express Railway provided adequate housing in Pocatello, Idaho. They housed braceros in barracks which they shared with regular non-bracero workers. These facilities had toilets, showers, tubs, places to wash clothes, doors with screens, adequate windows, proper heating, proper lighting, and a janitor. ${ }^{27}$ Bracero Juan Contreras recounted how he received adequate housing and that his bed linens were changed every three days. ${ }^{28}$ The overall inconsistency of housing for braceros is another example of how the program was not effectively monitored by either the Mexican or United States governments. The fact that some workers received good housing while other workers received terrible housing shows that there was either little effort or not enough resources put into checking whether standards were being up kept in every single institution.
Besides issues with housing, the main reason braceros went on strike was because of poor working conditions and disputes over wages. Some employers introduced braceros to dangerous chemicals that were harmful to their health. In certain orchards it was not uncommon for lead arsenate to be used as an insecticide. As a result, in a four-month period in 1945 there were seventy-eight cases of lead poisoning in the Northwest among Mexican laborers. ${ }^{29}$ Braceros who worked in roundhouses were constantly exposed to deadly gases and materials such as creosote, asbestos and chromate. Since most of these workers were uneducated they often did not wear masks or safety equipment. It was also difficult for farmers and foremen to provide safety instruction to braceros as most of them did not speak Spanish and most braceros did not speak English. ${ }^{30}$ Two years before the bracero program was enacted, railroad worker fatalities numbered 533 in the United States. In 1942, the inaugural year of the program, that number skyrocketed to 9,451 fatalities. $^{31}$

Throughout Washington, Idaho, and Oregon there were advisory committees that were made up of local farmers who discussed appropriate wage rates for their Mexican workers. Braceros were rarely asked to give input to these committees about the issues concerning their labor, or their wage rates. Even when these boards had good intentions, they were often slow and inefficient. These boards also had little administrative power and could easily be ignored by local farmers. ${ }^{32}$ Many of these 
boards also favored treating local farm hands more generously than the bracero workers. For example, the Idaho State Farm Labor Advisory Committee publicly stated that the experienced American farm hands should be paid a higher wage than braceros for the same work. When braceros would dispute their wages with their employers, it was not uncommon for the employer to remind the worker that they were required to work under the contract they were given. For example, in May 1944, bracero workers threatened to go on strike over a wage dispute, and in response the farmers told them that if they went on strike they would call the immigration authorities to have them deported for breaking their contract. ${ }^{33}$ Bracero workers had little recourse against abusive farmers, as there was no easy way to alert Mexican officials of abuse. In one example a farmer beat a bracero worker so badly that he needed to receive medical attention. No punishment was given to the farmer, and because there was not much the worker could do, the Mexican consul was of little help. ${ }^{34}$

Since workers could not rely on the Mexican or United States government to settle their labor disputes, braceros had to take measures into their own hands. The main intent behind most of the bracero strikes in the Northwest was to show farmers and the United States government that they could bring agricultural work to a halt. This was particularly troublesome considering the high demand for agricultural goods to feed the war effort. In Nampa, Idaho over a thousand bracero workers went on strike for nine days due to a dispute over wages. ${ }^{35}$ The strike originated in Nampa on June 17, 1946 but then spread across Idaho. Eventually workers from the Marsing, Franklin, Upper Deer Flat, and Amalgamated camps joined in on the strike. The workers only agreed to go back to work on the $26^{\text {th }}$ under instruction from the Mexican consul. ${ }^{36}$ In an official report from the state supervisor of the Emergency Farm Labor Program in Oregon, he wrote that the majority of labor camps throughout the state were bogged down with labor unrest. 1945 saw a wave of strikes throughout Idaho and Washington. In Walla Walla, braceros went on strike for twelve days over a wage dispute. In July of 1945, fifty new braceros had been transferred to a cherry picking facility in Idaho Falls. These new workers refused to work at the same wage rate the old workers had been making. As a result, the old and new workers went on strike in unison for a week, 170 workers in total. ${ }^{37}$

Although strikes were common for bracero workers of the Northwest, there are some workers who look back on their time as a bracero positively. The bracero program allowed a number of poor rural Mexicans to earn more money than they could have at home. Rodolfo Cruz Figueroa fondly remembers how he was able to travel on the weekends and enjoy himself when he worked as a bracero. He thinks that being a bracero was a positive experience in his life as it gave him the income he needed to buy a house and land. ${ }^{38}$ Juan Contreras remembered how life as a bracero was not always so serious and that sometimes camp 
managers would host events like dance lessons or supply the workers ice cream. ${ }^{39}$ Francisco Murillo Almaráz began working in the United States as a bracero and eventually went on to work in the United States for fifty-seven years and became a United States citizen. ${ }^{40}$ Other braceros were also provided with opportunities because of their work. In Walla Walla, braceros could take English classes at the local YMCA. It was also not uncommon for braceros to pull resources together and have extravagant celebrations, which were encouraged by their bosses. ${ }^{41}$ Most braceros were able to return to Mexico with much more wealth then they had arrived with. One item that was common for braceros to purchase before their return to Mexico were radios. Some workers even returned to the United States after the program had ended to set up a permanent life in the Pacific Northwest. Mexican communities, such as Granger, Washington, exist today in the Northwest thanks to the bracero program. ${ }^{42}$

The bracero program was presented as program that would be beneficial to both poor rural Mexican laborers, and the farmers of the United States. The braceros had a demand for money and the United States had a demand for labor. Braceros who were sent to work in the Pacific Northwest had a notable disadvantage compared to bracero workers of the Southwest, mainly due to being such a distance from Mexico. There was little support for the bracero workers of the Northwest to be protected from poor labor conditions due to the workers being placed in an area so far from Mexico. While the American government had little incentive to help these workers, the Mexican government simply did not provide the resources to help them. As a result, these laborers had to organize and mobilize themselves as a force against American agricultural production through work stoppages to have their voices heard.

Some bracero workers had a good experience working in the United States while other had a terrible one. The luck of each worker depended completely on where they were assigned by the United States government. Since the braceros were only allowed to work under the contract given to them by the United States, they had no option to leave an abusive employer if they wanted to continue making money. Their only recourse was to find help from the Mexican government, who put more time and attention into monitoring the American Southwest than the American Northwest. In reality the American government had no incentive to protect the rights of bracero workers, because their main concern was an increased production of war goods, no matter what the working conditions were. As a result of the neglect of the Mexican and American governments, the bracero workers of the Northwest took action of their own in order to improve their conditions. 


\section{NOTES}

${ }^{1}$ Erasmo Gamboa. Mexican Labor and World War II: Braceros in the Pacific Northwest, 1942-1947. (Austin: University of Texas Press, 1990).

2 Rivas-Rodriguez, Maggie. Mexican Americans \& World War II. $1^{\text {st }}$ ed. (Austin: University of Texas Press, 2005), 270.

${ }^{3}$ Rivas-Rodriguez, 272.

${ }^{4}$ Erasmo Gamboa, 24.

${ }^{5}$ Ibid, 27.

${ }^{6}$ Rivas-Rodriguez, 270.

7 "U.S. to let mexican farm workers enter to relieve shortage" Wall Street Journal, August 7, 1942.

${ }^{8}$ Rivas-Rodriguez, 275.

${ }^{9}$ Erasmo Gamboa, 41.

${ }^{10}$ Oregon Experience:The Braceros. DVD. 2007. Portland: Oregon Public Broadcasting), Video.

${ }^{11}$ Murillo Almaráz, Francisco, "Francisco Murillo Almaráz," in Bracero History Archive, Item \#297..

${ }^{12}$ Mario Jimenez Sifuentez. Of Forests and Fields: Mexican Labor in the Pacific Northwest. Latinidad. (New Brunswick, New Jersey: Rutgers University Press, 2016), 13-14.

${ }^{13}$ Domínguez, Violeta, "Miguel Arroyo Castillo," in Bracero History Archive, Item \#131.

${ }^{14}$ Murillo Almaráz, Francisco.

${ }^{15}$ Rivas-Rodriguez, 283.

${ }^{16}$ Erasmo, 75.

${ }^{17}$ Ibid, 43.

${ }^{18}$ Ibid, 77.

${ }^{19}$ Ibid, 53.

${ }^{20}$ Catherine Vezina. "Labor Strategies and Agribusiness Counterstrike during the Bracero Era: The Peculiar Case of the National Farm Labor union, 1946-1952.” Labor History, 2016.

${ }^{21}$ Sifuentez, Mario, "Juan Contreras," in Bracero History Archive, Item \#401.

${ }^{22}$ Mario Jimenez Sifuentez, 29.

${ }^{23}$ Domínguez, Violeta, "Miguel Arroyo Castillo," in Bracero History Archive, Item \#131.

${ }^{24}$ Erasmo, 93-97.

${ }^{25}$ Oregon Experience:The Braceros.

${ }^{26}$ Rivas-Rodriguez, 278-280. 
${ }^{27}$ Ibid, 278.

${ }^{28}$ Sifuentez, Mario, "Juan Contreras."

${ }^{29}$ Erasmo, 69.

${ }^{30}$ Rivas-Rodriguez, 283.

${ }^{31}$ Ibid, 282.

${ }^{32}$ Erasmo, 75, 78.

${ }^{33}$ Ibid, 81.

${ }^{34}$ Ibid, 82.

${ }^{35}$ Oregon Experience:The Braceros.

${ }^{36}$ Erasmo, 75.

${ }^{37}$ Ibid, 80-82.

${ }^{38}$ Domínguez, Violeta, "Rodolfo Cruz Figueroa," in Bracero History Archive, Item \#134.

${ }^{39}$ Sifuentez, Mario, "Juan Contreras.

${ }^{40}$ Murillo Almaráz.

${ }^{41}$ Erasmo, 107, 110.

${ }^{42}$ Oregon Experience:The Braceros. 